\title{
Multiculturalisms: An overview of multicultural debates in western societies
}

\author{
Enzo Colombo
}

abstract This article presents an overview of multicultural debates in Western societies. It introduces the key theoretical approaches, the main criticisms and it identifies current and future topics of discussion and analysis.

keywords cultural difference - inclusion/exclusion - recognition - cultural rights - integration

résumé Cet article présente un aperçu des débats multiculturels dans les sociétés occidentales. Il introduit les principales approches théoriques ainsi que les principales critiques. Il identifie également les sujets actuels et futurs de discussion et d'analyse.

mots-clés différence culturelle - inclusion/exclusion - reconnaissance - droits culturels - intégration

resumen En este artículo se presenta un resumen de los debates multiculturales en las sociedades occidentales. Se introducen las principales perspectivas teóricas, así como las principales críticas. También identifica los temas actuales y futuras de la discusión y el análisis.

palabras claves diferencia cultural - inclusión/exclusión - reconocimiento - derechos culturales integración

\section{Introduction}

The term 'multiculturalism' has become very popular in the last few decades and, as often happens to popular words, it has ended up expressing quite different meanings. In this short essay, only a very concise and (personally) selective presentation of the current debate and the rich literature on this subject is possible. In fact, multicultural discussions refer to a wide variety of situations - integration policies and welfare-state regimes, the legal and political accommodation of cultural diversity, the management of immigration and national borders, the recognition and respect of cultural/religious difference, living with 'difference' in daily contexts, the ideological representation of identities, cultures and 'the good society', to name only a few. These also involve different disciplines philosophy, sociology, anthropology, social psychology, political science, pedagogy, and cultural and post-colonial studies - with their own distinct questions, perspectives, and tool-kits. All this justifies the use of the term in the plural to highlight its polysemy and accounts for the inevitable partiality of this presentation, which mainly focuses on Western societies.

This essay aims to offer the necessary coordinates to locate these debates in an approximate, although I hope useful, map. It starts exploring the various meanings difference can assume in the debate on multicultural societies. The second section sets out the main ways in which multicultural issues have been developed and critically discusses some aporias of the multicultural perspectives. The third section presents the alleged current multiculturalism backlash, while the final part highlights some current directions of research. 
Generally speaking, multiculturalism refers to situations in which people who hold 'different' habits, customs, traditions, languages and/or religions, live alongside each other in the same social space, willing to maintain relevant aspects of their own difference and to have it publicly recognised. Usually the term involves a positive evaluation of cultural diversity and the institutional commitment to its preservation. Multiculturalism is closely associated with 'identity politics', 'the politics of difference', and 'the politics of recognition', all of which consider proper recognition of cultural diversity a necessary step towards revaluing disrespected identities and changing dominant patterns of representation and communication that marginalize certain groups (Song, 2010). In fact, the kind of difference multiculturalism emphasises and the recognition it claims can be quite disparate.

First, multiculturalism may refer to claims of recognition by native and sub-state national groups (Kymlicka, 1995). In relation to indigenous populations - such as Aboriginal peoples in Canada and Australia, American Indians, the Maori in New Zealand and the Inuit in Greenland - multicultural debates put forward the issues of the endowment of rights for minority groups that have been subjugated, exploited and discriminated against by (white European) foreign conquerors. Natives were subjected to systematic and persistent violence, both physical and symbolic, and they now occupy marginal positions in economic, political and social life, where their capacity to participate on a par is restricted by negative representations and prejudices. The debate focuses on the opportunity to endorse specific policies in support of indigenous people to overcome long-standing injustices and lingering inequalities. The policies may include land rights, self-government rights, recognition of customary laws and adequate political representation in nation-state institutions as well as the promotion of anti-discrimination campaigns or the symbolic recognition of the role of these native groups in the shared history of the country. In relation to sub-state national groups - such as the Quebecois in Canada, Basques and Catalans in Spain, Corsicans in France, Flemish and Walloons in Belgium, Scots and Welsh in Britain, Germans in South Tyrol, and Swedes in Finland multicultural debates mainly focused on policies such as federal or quasi-federal territorial autonomy, self-determination rights, guarantees of representation in the government, and official language status, at either the regional or national level.

A second way to address cultural difference is related to discriminated groups within society. Typically, this debate has to do with issues of race and gender. Integration and discrimination of 'racially marked' minorities and the position of women in society are cases in point, representing two of the thorniest questions concerning the difficulties of liberal democracies to move from formal egalitarianism to effective equality for all citizens. Although formal discrimination has been eliminated, both racialized groups and women are under-represented at the topmost levels of economic, academic, and political institutions; they usually have higher unemployment rates and suffer forms of symbolic violence that entrap them in misrepresentations and marginal social positions. They are often depicted as inferior, lacking, irrational, and unfit for power and leadership. The multicultural debate focuses on the necessity for affirmative action policies favouring members of these disadvantaged groups and allowing them to overcome negative social representations. Affirmative action may either consist of a specific quota reserved for members of disadvantaged groups in higher education, on corporate boards, at the top levels of university and in parliament, or it may consist of preferential treatment in selection processes. The debate also introduces the need for specific politics of difference (Young, 1990), i.e., a more radical revision of the criteria used to allocate social positions and material goods. In this case, previous policies of assimilation and inclusion are accused of bias towards white males and of being presented as neutrality- and impartiality-led, but succeed only in universalising the experience of those in power. Affirmative measures should be taken to ensure that marginalized groups gain access to the social forum on an equal footing. This may entail different rules and separate, exclusive organizations for oppressed groups to enable them to engage in consciousness raising and empowerment processes.

While race and gender are 'two-dimensional' or 'bivalent' forms of discrimination and require redress in the forms of both distribution and recognition, other types of difference can be primarily discriminated against on a symbolic basis. This is the case of the so-called despised sexualities, groups 
whose state of oppression stems from cultural devaluing rather than political economic arrangements and who suffer injustice due to prejudice and misrepresentations (Fraser,1997). Multicultural debates promoted by these groups stress the importance of cultural dimensions. They deconstruct the alleged 'normality' showing how what is presented as 'natural' and 'universal' is, in fact, the result of the imposition of the dominant rules and ask for appropriate recognition, only possible by changing current cultural patterns of interpretation, communication, and representation.

Multicultural debates in North America mainly encompass native peoples and cultural minorities, in Europe however, they refer to a post-immigration urban mélange and the politics it gives rise to (Triandafyllidou et al., 2012). In this case, cultural difference refers to immigrants, and multicultural issues entail overcoming previous assimilationist or colonialist patterns of migrants' inclusion in favour of the recognition of immigrants and their offspring's right of being part of society without complete identification with the majority group. Multicultural policies include the funding by the state of ethnic group organizations to support cultural activities and preserve ethnic traditions, the funding of bilingual or mother-tongue education, the exemption from dress codes and the recognition of specific forms of legal and political pluralism, including multiple jurisdictional systems, especially when warranted by religious beliefs or ethnic customs. Immigrant multiculturalism also includes claims for facilitated access to citizenship, including the possibility of dual citizenship.

Multiculturalism for immigrant groups clearly differs in substance from that of indigenous people, the internally discriminated or that of cultural minorities. Nevertheless, all of them, although in different measures, raise the same relevant issues:

- To promote more democratic inclusion, assuring real equal access and participation for all members of society without subordinating inclusion to assimilation into the majority group;

- To overcome previous offensive and undemocratic relations of domination and exclusion, recognising the violence and exploitation by the members of the dominant group who impose their own rules and ideas by presenting them as 'natural' and 'universal';

- To take part in the debate on the 'rules of the game' for participation and to have a say in how to build a fairer, more equal society;

- To assure adequate recognition of and respect for cultural difference, fighting stereotypes and prejudices that depict minority groups in negative ways and entrap minority group members in despised identities;

- To recognise the right to be different, to hold different religious beliefs, sexual identifications and preferences, plural identifications and multiple citizenship without being discriminated or excluded.

- To give relevance to 'culture', 'cultural groups', and 'cultural rights' (Levy, 2000), not only to individual rights.

\section{Theoretical approaches}

Multiculturalism applies not only to diverse types of difference within society, it also entails various, although intertwined, theoretical perspectives that pose specific questions and highlight distinctive aspects of living with diversity in current societies. In the following section, three approaches to multicultural issues are introduced and critically discussed.

\section{Multiculturalism as a normative issue}

A large part of the multicultural debate in the 1990s was monopolised by political philosophy in the effort to develop a coherent theory of justice able to include a relevant space for group rights and the recognition of cultural difference. As political theory, multiculturalism challenges a liberal philosophy of universalism that conceives human beings as rational agents of free will, whose freedom may be granted only through identical, individual rights. It stresses the importance of the recognition of difference both at the philosophical level - its importance for personal identity, selffulfilment and social participation - and at the political level - its importance for giving a voice, in the public space, to marginalised groups, overcoming previous injustice and exploitation. 
Countering the liberal idea that emphasises unity and sameness, a communitarian perspective valorises difference and group membership. It states that recognition of individual rights is not enough because it presupposes an incoherent notion of the individual as existing outside and apart from social relations, rather than embedded within them. An appropriate recognition of both individual and group difference establishes the basis for full development of individual capacities and for fair and democratic participation in social life (Taylor, 1994; Honneth, 1996). People can build an independent and self-confident identity only through dialogue with others, feeling part of a particular, distinct community. Individual agency depends on belonging to particular social and cultural groups that provide individuals with meaning. When the specificity of this community is ignored, glossed over, assimilated into a dominant or majority identity, or misrecognised, a person or group of people can suffer real damage, real distortion (Taylor, 1994: 25).

Liberal universalism and cultural neutrality are contested too. Different cultures represent different systems of meaning and visions of the good life and no single one of them may claim to give appropriate answers to the totality of human existence. No culture is perfect and no culture has the right to impose itself on others (Rorty, 1989; Hollinger, 1995; Parekh, 2002). Consequently, diverse cultural identities should be presumed to be of equal worth and the traditional liberal principle of identical liberties and opportunities for all citizens should be replaced with a regime of special rights for minority cultural groups (Song, 2010).

Defenders of liberalism (Schlesinger, 1998; Barry, 2001; Huntington, 1996, 2004) observe that liberal democracy requires a common cultural basis and a strong feeling of civic engagement in order to function. They sustain that the politics of difference contrast with the politics of solidarity because recognition of group rights fragments society, promotes 'parallel lives', withers loyalty to the nationstate, reduces individual freedom, and undermines a politic of redistribution (for a similar criticism from a progressive point of view, see Gitlin, 1995).

A significant attempt to overcome a rigid contraposition between individual and collective rights has been proposed by Willy Kymlicka (1995). Endorsing the liberal values of freedom of choice, personal autonomy and equality, he stresses the importance of culture and cultural membership. Cultural membership matters and cannot be easily expunged from liberal theory because culture provides its members with a meaningful way of life and defines the range of options from which individuals can choose. It also provides the necessary environment for developing individual self-confidence and self-respect. A fair society should recognize the importance of minority cultures and allow their members to protect their culture against majority practices and rules. Nevertheless not all the claims of cultural protection can be accepted on a liberal basis. Kymlicka distinguishes between 'external protections' - the demand by a minority culture to protect its distinctive existence and identity by limiting the impact of the decisions of the larger society - and 'internal restrictions' - the demand by a minority culture to restrict the basic civil or political liberty of its own members in order to maintain internal status quo, to prevent group fragmentation or to contrast internal dissent. While 'external protection' claims are fully compatible with liberal principles and should be accepted because they help to enhance individual freedom and social justice, 'internal restriction' requests must be rejected. Jürgen Habermas (1994) shares the idea that the protection of collective identities does not necessarily conflict with the right to equal individual liberties. He sees the possibility of linking the two apparently irreconcilable principles when attention for the 'contents' of multicultural policies is replaced by a 'proceduralist' conception of rights according to which the democratic process has to safeguard both private and public autonomy at the same time. Safeguarding the private and individual autonomy of citizens with equal rights must go hand in hand with activating their autonomy as citizens participating in public life. Rather than concerns about which kind of policy to promote, it is preferable to focus on the 'conditions' for a free, public discussion in which all citizens, from their specific cultural location, have a say in the definition of the common binding rules. A fair multicultural society does not depend on some specific, real and well-defined set of juridical norms and policies. Instead, it is the result of 'constitutional patriotism', a public agreement on the rules for claiming recognition and taking decisions affecting all members of the society. Seyla Benhabib 
(2002) further develops the centrality of deliberative democracy for multicultural debates. She considers one of the most widespread criticisms against the communitarian perspective - namely its tendency to reify culture, conceived as fixed, stable and characterised by well-defined boundaries and argues that the principles of liberalism and the acceptance of cultural and religious traditions may be easily arranged if three conditions are met. Society and groups who claim cultural recognition must grant their members: 'egalitarian reciprocity' (members of minorities must not, in virtue of their membership status, be entitled to lesser degrees of rights than the majority); "voluntary selfascription' (an individual must not be automatically assigned to a cultural, religious, or linguistic group by virtue of his or her birth); 'freedom of exit and association' (individuals must have unrestricted freedom to choose which group they belong to and to move from one belonging to another).

\section{Multiculturalism as an (anti)ideology}

An original and important theoretical contribution to the 'multicultural debate' comes from a strong criticism of universalism. Since the 1960s and especially the 1970s, de-colonisation movements and postcolonial theory have denounced the universalism of those in power whose celebration of alleged universal values, in fact, conceals practices of domination and exploitation (Wieviorka, 2013). Feminist theory, radical social theory and postmodernism have played a relevant role in the debate. Although in different ways, all these theoretical perspectives defied universalism giving priority to situation, socio-historical variability and contingency; they stimulated an open war over the 'canon' (Derrida, 1972, Rattansi, 1999) and a radical deconstruction of - white, male - domination; they also contributed to carrying on an acute critique of patriarchal societies (Narayan and Harding, 2000) and Eurocentrism (Shohat and Stam, 1994).

Criticism of universalism also entails criticism of fixed identity and exclusive belonging. A constructivist point of view is supported against an essentialist standpoint that conceives identity and difference as the deepest and more authentic nucleus, which is the basis for the existence of the individual and the group. Identity and difference are seen as products of continuous mediation, comparison, adjustment, translation, and conflict between differentiated possibilities (Amselle, 1990; Hannerz, 1992; Young, 1995). Current economic and cultural globalization as well as migratory phenomena contribute to undermining the idea that individuals and groups are characterised by single and permanent identities, and that the nation-state can be synonymous with universal values (Beck, 2006).

Ethnic difference, in particular, is seen as a result of power and violence, the outcome of hierarchy and conflict that distinguish imperial and colonial power (Gilroy, 2006). Western societies - and not only Western societies - are and have always been 'multicultural'. Current political multiculturalism - as well as its critics - focuses on ethnic and religious difference, depicting it as a 'natural given'; in so doing, it neglects the power and the violence that produce such a difference (Gilroy, 2005).

While liberal multiculturalism defends ethical universals - freedom, autonomy, tolerance - and communitarianism emphasises group membership, critical multiculturalism (Goldberg, 1994; May, 1999) is about empowering the disempowered, contesting dominant groups, challenging their 'canon' and transforming their institutions and discourses. It highlights differences 'within' groups, not only difference 'between' groups (Yuval-Davis, 1999). It is not about the 'recognition of difference', as a pure acknowledgement of the existence of reified and stereotyped 'others' which should be 'included'; instead, it critically focuses on the social and political construction of white male supremacy and the dispensation of white male hegemony. The deconstruction of dominant positions, rather than the recognition and the inclusion of the dominated, becomes the focus of analysis (McLaren, 1997). What is really at stake in the multicultural debate is neither the recognition of identity nor the endorsement of collective rights but the unmasking of the foundation of (white, male) domination (Hage, 2000). Multiculturalism, in this case, unveils racism and counters the invisible and taken-for-granted presuppositions that define the setting for the entitlement of rights, power and 
privileges; it also constitutes a re-adjustment of unequal relations of power and exploitation between dominants and the dominated (Hall, 2000).

Put into its precise historical perspective, multiculturalism is not the result of the encounter between 'pure' and 'well-defined' culturally different groups; instead, it is the attempt to redefine power relations between mixed and changing forms of political identification (Gunew, 2004). The binary contrast between the particularism of 'minority' demands for the recognition of difference versus the universalism of the 'majority' civic rationality is rendered impracticable by the post-colonial experience. It becomes evident that there are - and there have always been - many relevant differences 'within' any group, and, therefore, also the alleged 'authenticity', 'homogeneity' and 'unity' of the 'autochthonous' is challenged (Hall, 2000). Rather than attesting the different nature of different cultures, multiculturalism highlights the character of social construction of any culture and identity; it shows that culture and identity are more the result of history and power than of biology or fate.

\section{Multiculturalism as a feature of current global societies}

In its descriptive terms, multiculturalism refers to some peculiar characteristics of current societies. It focuses not only on the way in which cultural differences are produced and reproduced, but also on the questions and tensions these processes generate, including the proposals for political and institutional procedures for dealing with them (Wieviorka, 1998).

Managing cultural difference is hardly a new phenomenon. In the past, societies we now call multiculturalists, were usually defined as 'multinational', 'multi-ethnic' or just 'plural'. Nevertheless, multiculturalism highlights specific aspects and poses specific questions. The point is that multiculturalism does not simply refer to the mundane fact that complex modern societies are characterised by cultural diversity; instead, it refers to the fact that the meaning attributed to cultural diversity in western societies has radically changed since the second half of the last century. Rather than being the simple result of a 'quantitative' increase of 'difference' or a 'demographic fact', it represents the effort to find a new cultural, legal and political accommodation of cultural difference, replacing older forms of social (gender, ethnic and racial) hierarchy (Kymlicka, 2012). Therefore, it is difficult to understand multiculturalism without putting cultural difference in its appropriate context. Cultural, economic and political factors - and their combinations - have been indicated as causes of a significant change in the notion of cultural difference following World War II (Semprini, 1997). Cultural factors refer to the role of the 'new social movements' (Melucci, 1996; Wieviroka, 1996; Touraine, 1997) and their struggle against assimilation and the melting-pot ideology (Rex, 1996). Multiculturalism is part of a larger human-rights revolution involving ethnic and racial diversity (Baumann, 1999; Kymlicka, 2012). Economic factors include the success of market ideology and the crisis of the Fordist model of production (Goldberg, 1994; Constant, 2000). Political factors embrace the end of the Cold War (Beck, 2006) and the subsequent crisis of nation-states (Habermas, 2001). Crisis that is also connected to the intensification of globalization processes, the changes in the characteristics of migration flows and the effort of the nation-states to control their boundaries (Bloemraad et al., 2008).

Sociological perspective insists on the social construction of identity and difference, countering essentialism and reification. It aims to show the inconsistency and pitfalls of considering national, ethnic and religious cultures as finished objects whose features have been defined through long historical processes and have now to be preserved unchanged. In this way, culture finishes to act as a deterministic device that influences and even shapes the actions and thoughts of all its alleged members, depriving them of agency (Baumann, 1999; Phillips, 2007). Without a sociologically informed concept of cultural difference, multiculturalism ends up fostering new forms of discrimination, only superficially masked by respect and recognition of difference. An all-too-quick reification of the identities of a given group has often frozen existing group differences, strengthening the position of specific elites within communities and reproducing ancient hierarchies. 
Yet, the essentialist view of culture cannot easily be dismissed because culture constitutes a political tool in arguing for rights and exemptions, recognition and group privileges. Effective social use of cultural difference requires a dual competence (Baumann, 1999): the capacity to produce and to overcome distinctions according to situations and personal and collective aims. Cultural difference needs a certain degree of credibility and stability in order to be effective, but risks losing this effectiveness if it cannot be adjusted to the specific situation in which it is used. Dual competence not only depends on the will or the sensitivity of the individual, but it also suffers under structural constraints and conditions of power which transcend the rational abilities and strategies of the person involved.

Multiculturalism poses the tricky question of combining difference and identity, reification and ongoing production, «drawing together on the same terrain those formal incommensurables of political vocabularies - liberty and equality with difference, 'the good' with 'the right'» (Hall, 2000: 235). Accepting and taking this ambivalence seriously may result in a more complex, fragmented and heterogeneous civil sphere (Alexander, 2001, 2013; Kivisto, 2010) that makes the expansion of democratic participation possible. Rather than being solved in the abstract, at the level of a new theory of justice, ambivalent requests coming from multicultural debates may be negotiated and reconciled in practice (Werbner, 2005; Wieviorka, 2013).

From this perspective, analysis focuses on the meaning and practice of multiculturalism, both at the level of state policies and of local relationships. Analysis draws attention to how cultural difference becomes a political tool for claiming rights and inclusion or, vice versa, it turns into a justification for exclusion. Multiculturalism is conceived as an on-going political accomplishment, a practical resource that can be used either in defence of (cultural, human) rights or in defence of communal solidarity.

\section{The multicultural backlash}

In 1997 Nathan Glazer published We are all multiculturalists now to suggest - maybe rather too optimistically - that recognition and respect of cultural difference had become a permanent feature of western society. Not many years later, around the turn of the millennium, we witnessed widespread talk of a necessary retreat from multiculturalism, which was a failure and had ended up fostering social fragmentation, parallel lives, and terrorist groups. The multiculturalism backlash became stronger also for a sequence of tragic events and hot debates that, notwithstanding their diversity, all have been important in influencing public opinion. First, there was a series of urban riots (Oldham, UK, in 2001, Paris banlieues, France, and Cronulla Beach, Australia, in 2005) described as fights between immigrants or children of immigrants and local youth. In the press and in political discourses, the riots were presented as being caused by the inability or unwillingness of immigrants to integrate, encouraged as they were to live parallel lives by generous multicultural policies that pushed them to feel apart from the rest of the population. Second, were the murder of the filmmaker Theo van Gogh in 2004 in the Netherlands, the 7/7 2005 terrorist bombing in London, and, more recently, the terrorist attacks at French satirical magazine Charlie Hebdo and the deadly siege at a kosher store in Paris, followed by similar episodes in Copenhagen a month later. The fact that the protagonists of these tragic events were mostly young European citizens, with immigrant background, caused harsh discussions in most western countries on the necessity to counter (Islamic) religious fundamentalism. As a result, talks of a necessary retreat from multiculturalism as a normative ideal and as a set of policies spread in all western countries. It may be useful to discuss in some detail four different criticisms.

\section{Conservative, right-wing criticism}

Conservative critics accuse multiculturalism of giving exaggerated support to minority group identities and cultures, in so doing weakening the original local culture. They often depict 'a zerosum war' between cultures (Huntington, 1996; Auster, 2004), with multicultural policies favouring illiberal, anti-modern and anti-democratic minority groups while blaming the majority group of being 
ethnocentric and racist. Uncritical acceptance of habits, customs, values and languages far from, if not opposed to, those of the majority, is diminishing western identity, its institution and its beliefs. Cultural pluralism, so the criticism goes, reinforces aggressive minority groups and neglects the value of the specific and unique history of liberal, democratic western culture, condemning it to extinction. The majority group must take pride in its own culture and enhance it by making the most of national belonging and internal cohesion. It must expect minority groups to observe majority rules and values and show willingness to assimilate before it grants them recognition and respect.

Islam is often the specific target of this criticism. Muslims are seen to be particularly reluctant to integrate and to adopt Western values, embracing fundamentalism and trying to impose their own laws and way of life. The retreat from multicultural policies and the rebalancing of tolerance are regarded as the necessary response to a clash between an aggressive, separatist and integralist Muslim identity and the liberal values of freedom of expression, separation of church and state, women's and gay rights.

'We must defend our identity' arguments have been criticised for considering identities and cultures as homogeneous and fixed, neglecting internal difference and conflicts. Reified cultures are presented as incommensurable and unavoidably destined to clash. In this way, a new form of racism is fostered (Poynting et al., 2004; Kundnani, 2012; Gilroy, 2012; Back et al., 2012) in which the focus moves from the biological notion of 'race' to 'race as culture, ethnicity and religion'. A new form of racism of which Islamophobia (Poynting and Mason, 2007; Modood, 2007; Romeyn, 2014) is its harshest manifestation.

\section{Is multiculturalism harmful for women?}

The alleged contraposition between multiculturalism and women's rights - although avoiding identity arguments - is also a central point of discussion for part of the women's movement. Susan Moller Okin (1999) observes that there could be a contradiction between the multicultural idea that all cultures are entitled to equal respect and concern and the protection of women's rights. Many of the cultures multiculturalism aims to protect do not accept the principle that people are owed equal rights, and they endorse practices that severely penalise some groups within the community. This is particularly true for women that are often - on the basis of alleged cultural, traditional or religious reasons - exposed to unfair treatment: differential nutrition and health care, unequal rights of ownership and political participation, unequal vulnerability to violence, and the denial of educational opportunities, to name only a few.

Migrant groups are often more patriarchal than the majority; allowing them to persist with their customs results in the collapse of women's freedom and the erosion of the hard-fought conquests of the women's movement. Establishing group rights to enable some minority culture to preserve itself may not be in the best interest of women, even if it benefits men. Actually, women of minority groups «might be much better off if the culture into which they were born were either to become extinct (so that its members would become integrated into the less sexist surrounding culture) or, preferably, to be encouraged to alter itself so as to reinforce the equality of women - at least to the degree to which this value is upheld in the majority culture» (Okin, 1999: 22-3).

Responses to Okin's remarks stress the pitfalls of a too clear-cut and simplistic division between western liberal society - deemed less patriarchal - and minority cultures. Western liberal regimes are not always 'less patriarchal' than other regimes; they are differently so (Honig, 1999). Recognising the various ways of looking at gender roles in other cultures might heighten western women's critical awareness of some of the limits, as well as the benefits, of a liberal way of life. The essentialist idea of culture is problematic also because it conceals differences within groups. Condemning practices is not the same as condemning so-called cultural groups, and cultural practices may have different meanings for 'insiders' and for 'outsiders' (Anthias, 2002). The possibility that women in other cultures may conceive freedom in another way is totally overlooked (Al-Hibri, 1999), with the risk of imposing the point of view of white dominant women as 'universal'. 


\section{National-solidarity criticism}

One of the most relevant criticisms blames multiculturalism for weakening social cohesion. Policies that allow minority groups to maintain their own cultures and identities encourage ethnic separatism and promote racial, ethnic and cultural balkanization (Goodhart, 2004; Malik, 2009). The current backlash is justified by the evident failure of multiculturalism policies, especially in incorporating migrants (Brubaker, 2001; Joppke, 2004). Rather than facilitating integration and improving equality, support and recognition of cultural difference of minority groups, these policies have promoted indifference and parallel lives. As a result, social cohesion has withered, eroding the very foundation of social life. Supporters of liberalism stress the importance of a shared sense of belonging in order to feel involved in public affairs, to participate in public life, and to manifest solidarity for the less privileged (Barry, 2001). Without a certain degree of nationalism, the idea of belonging to the same community and sharing a language, democracy is at risk. Liberal states have to impose liberal principles and a community cohesion agenda must replace multiculturalism if we want to make a progressive shift towards realistic recognition of the ambivalent task for any liberal democratic state: to grant solidarity among members and encourage recognition of (individual) particularity (Joppke, 2008; Thomas, 2011). In order to promote effective integration of minority groups, the state must promote what is common and shared over what is specific and divisive. Insisting that the minority group share the fundamental principles of the majority's way of life, its language, and its institutions fosters integration and equal social participation (Miller, 2002). Rather than pushing migrant groups to preserve their traditions, state policies should promote the values of freedom and democracy because effective integration requires a genuine willingness to accept and endorse the core values of western societies. Social cohesion (or 'civic integration') policies should replace multicultural policies, for a successful incorporation into a host society rests not only on economic and political integration but also on individual commitments to characteristics typifying national belonging: knowledge of the history of the country, language proficiency and explicit endorsement of liberal and social values (Goodman 2010: 754; Joppke 2007).

Integration cannot be the initiative solely of the majority. In order to be integrated migrants must show their desire to be so, and accept the sacrifice of giving up aspects of their own culture that do not fit into that of the majority. Making immigration policies more selective, welfare benefits not immediately available to new immigrants, and strengthening the symbolic aspects of citizenship (Goodhart, 2004) all help in giving support to redistributive welfare state programs and allow for effective social equality.

These criticisms have been accused of supporting a regressive step towards coercive and ethnocentric assimilationism (Back et al., 2002). Social cohesion stresses moral and social order and echoes the traditional view of social integration as social control. It reduces community belonging to mechanical solidarity, homogeneity, and sameness. Equality and social justice are replaced by an emphasis on belonging, inclusion, governance, absence of conflict, and co-responsibility (Eizaguirre et al., 2012). Another important shift occurs (Ratcliffe and Newman, 2011): ethnic and religious difference (and its recognition by the state) are blamed for a lack of integration and social cohesion that, in fact, is mainly due to structural inequality and poverty.

\section{Progressive criticism}

The alleged multiculturalist failure to redress socio-economic inequality is the specific focus of progressive criticism. From this point of view, multiculturalism overstressed culture, concealing the real economic reasons for the discrimination and exclusion of minority groups. Under the apparently favourable intention of protecting cultural difference, the reality that minority groups suffer harsh inequality remains hidden. The supposed difference multiculturalism policies aim to recognise and preserve is, actually, negative disparity in education, employment, rates of incarceration, and housing conditions. Overcoming social discrimination may require more redistribution than recognition or, at least, a mix of the two (Fraser, 2007). 
Integration requires social cohesion as well as policies against discrimination and poverty. Discriminated people cannot be empowered by protecting their culture - which often means separation and indifference - instead, they need material help. They ask for participation and inclusion rather than to be left in isolation; their decision to migrate is proof of their desire to leave their traditions behind and embrace the lifestyle of the country in which they settle. Asking them to commit to learning and using the language and adopting the way of life is not an imposition of majority rules; instead, it is a necessary step towards their effective integration.

A more realistic policy is needed in which both protection against discrimination and social cohesion is granted. Rather than policies that promote 'bonding' social capital - that is, cohesion 'within' defined communities - the state must promote policies that strengthen 'bridging' social capital - that is, overlapping networks 'between' different communities (Putnam, 2000). The former include assistance in preserving the minority language and traditions; the latter support the learning of the necessary linguistic and behavioural skills for communication and being accepted as part of the community. From this point of view, multiculturalist policies that supported the preservation of minority culture have been deleterious because too much cultural difference erodes the level of bridging capital, hindering immigrants' civic and political participation.

Progressive criticisms have been accused of promoting a new form of assimilation in which the dominant culture is reified and minorities are required to endorse it and fit in as a condition for their acceptance and participation (Ong, 1999). By relating belonging to social cohesion, the first becomes a pre-requisite for the second (Yuval-Davis et al., 2005) transforming integration into a new form of discipline and control that selects immigrants deemed 'good' and 'helpful' while legitimising the exclusion of those considered 'too diverse' and not willing or able to integrate.

\section{Trends in current research on multicultural societies}

\section{Assessing multicultural policies}

The effective consistency of the multiculturalism backlash is hotly debated and the greater part of current empirical research focuses on assessing the magnitude and effectiveness of multicultural policies (MCPs), correlating diverse multiculturalism indices with different outcomes.

An initial direction of analysis agrees with the existence of a retreat from multicultural policies in current western societies but disputes that this is due to a failure of such policies. It focuses instead on growing hostility to immigration and on concerns about unemployment and the economic condition (Lentin and Titley, 2012; Pakulski and Markowski, 2014). Migrants - especially illegal and 'false' asylum-seekers - are accused of welfare parasitism, reluctance to integrate and criminality. All this generates a climate of antagonism and hatred for immigrants and legitimises policies that restrict immigration and immigrant rights. Political leaders exploit this trend and ride the wave of public approval to gain consent, describing multiculturalism as a failure and promoting less tolerant and more assimilationist policy strategies (Lesińska, 2014; Walsh, 2014).

A second important trend of analysis questions the real magnitude of the multiculturalism backlash (Vertovec and Wessendorf, 2010; Rattansi, 2011; Kymlicka, 2012). Criticism of multiculturalism succeeds because it depicts multiculturalism in a simplistic and distorted way. Current criticisms target 'strong multiculturalism' - institutional recognition for difference in the public sphere, with special provision for language and welfare state benefits for members of minority groups - which has rarely been implemented. Effective multiculturalism policies are closer to a 'weak multiculturalism' (Grillo, 2007) which aims to avoid discrimination of minority groups in employment, housing, education, health and welfare. This form of multicultural integration remains a valid option for Western societies.

Recently, drawing on an updated version of the Multiculturalism Policy Index (MPI) - introduced by Banting et. al (2006) - Banting and Kymlicka (2013) give an accurate assessment of the alleged wholesale dismissal of multiculturalism in favour of civic integration policies. The current version of MPI accounts for the presence or absence of multicultural policies in 21 Western democracies in three 
distinct years: 1980, 2000 and 2010. It scores each country for each point in time, depending on the extent to which it has implemented eight different policies: formal legislative or parliamentary affirmation of multiculturalism; adoption of MCPs in education; inclusion of minority representation/sensitivity in the mandate of public media; exemption from dress codes, Sundayclosing legislation, etc.; allowing dual citizenship; funding of minority organizations to support cultural activities; funding of bilingual or mother-tongue education; affirmative action for disadvantaged minority groups. (The index is available at http://www.queensu.ca/mcp/).

The diachronic international comparison shows that while a small number of countries, including most notably the Netherlands, have weakened established MCPs during the 2000s, such a shift is the exception. Actually, most countries that adopted MCPs at the end of the twentieth century have retained their programmes in the first decade of the new century, and a significant number of countries have added new ones. Based on these data, Banting and Kymlicka affirm that there is no evidence for a multiculturalism retreat nor for a shift from MCPs towards civic integration policies. The latter are often layered on top of existing multicultural programmes, leading to a blended approach to diversity. The authors conclude that MCPs are still important for the promotion of effective and fair minority integration.

A more critical assessment of multicultural policies emerges from Ruud Koopmans' (2013) analysis. Comparing cross-national differences in multicultural policies on the basis of two indexes - the MPI and the Indicators of Citizenship Rights for Immigrants (ICRI) - he suggests that multicultural policies have had little effect on socioeconomic integration, some positive impact on political integration, and negative effects on sociocultural integration. In particular, when multicultural policies combined with a generous welfare state they have led immigrants to depend on welfare benefits and hence to social and economic marginalization, lowering incentives to acquire the linguistic skills and interethnic contacts (Koopmans, 2010).

Citrin and colleagues (2014), correlating MPI with attitudes towards immigration and political support in 16 European democracies that have experienced significant immigration in the past decade, observe that extensive adoption of multicultural policies magnifies the degree to which hostility to immigration is negatively associated with political support. They state that multiculturalism widens the gap in political support between pro- and anti-immigrant opinion groups, furnishing on-going opportunities for rightist fringe parties to capitalize on anti-immigrant sentiment among the politically alienated.

The hypothesis that public support of cultural difference induces people to distrust their neighbours and engage less in public life (Putman, 2007) has been thoroughly investigated with opposing results. While some studies have found diversity to have negative effects on social cohesion and national identification (e.g. Anderson and Paskeviciute, 2006; Laurence, 2011; Agirdag et al., 2011) and on immigrant integration (Wright, 2011), others have not (e.g. Hooghe et al., 2009; Sturgis et al., 2011) or suggest that MCPs increase social trust in more economically equal societies (Kesler and Bloemraad, 2010), reduce social distance (Heath and Demireva, 2014) and decrease anti-minority prejudice (Weldon, 2006).

The effects of MCPs on the welfare state have been extensively analyzed by Banting and Kymlicka (2006). Their studies suggest that public recognition and support for ethnocultural minorities to maintain their distinct cultural characteristics help to strengthen the welfare state rather than having a corrosive effect. They conclude that there is no evidence of MCPs eroding trust, solidarity, or support for redistribution. Other studies (Bloemraad, 2006; Wright and Bloemraad, 2012) show that MCPs can facilitate immigrants' collective action and political participation, supporting sociopolitical inclusion and promoting civic integration.

These differing results in assessing the effects of MCPs suggest the necessity of a more cautious use - and a more precise operationalization - of multi-faceted and dynamic concepts such as social cohesion, belonging, identification and integration (Reitz et al., 2009; Ariely, 2013). They also push to further disaggregate multiculturalism and leave adequate room for the variations within and between countries in policies and discourse directed at cultural minorities. Rather than assessing 
MCPs as a whole, the contradictory results invite analysis of what effects, if any, specific MCPs have on particular outcomes in diverse contexts.

\section{Analysing multicultural attitudes and identity}

A second important trend of research concerns the socio-psychological effects of multiculturalism, especially on inter-ethnic attitudes and interactions, multicultural education and multicultural identity (Arasaratnam, 2013). In this case, multiculturalism is mainly conceived as regarding individual attitudes, groups and group identities, rather than state policies (Verkuyten and Martinovic, 2006). Many studies discuss topics that relate to majority and minority group attitudes towards multiculturalism and the variables that influence them. Overall, this type of analysis underlines a difference between majority and minority attitudes towards multiculturalism. Minority group members generally prefer to maintain their own culture and show more favourable attitudes towards multiculturalism than majority group members (Verkuyten and Thijs, 2002; Liu, 2007). Their endorsement of multiculturalism can be seen as both a strategy to improve their social status and a reaction towards perceived discrimination. In contrast, majority group members generally prefer that the minority be assimilated (Zagefka et al., 2007). The more the majority group members identify with their in-group, the more they can be expected to try to protect their group interests and status (Verkuyten \& Brug, 2004). Older, less educated people and extrinsic believers - characterized by an instrumental approach to religion - generally show less favourable attitudes towards cultural diversity.

These differences are mainly interpreted into the framework of group threat theory (Quillian, 1995; McLaren, 2003; Evans and Need, 2002). The (realistic or perceived) threat from a minority and subordinate group is often seen as the single best indicator of negative attitudes towards out-groups (Paxston and Mughan 2006).

John B. Berry (1974, 1980; Berry et al., 2006) elaborates an influential typology for studying acculturation (i.e. the ways people prefer to live in intercultural contact situations), using it to assess personal adjustment (behavioural competence and psychological and emotional wellbeing) and intercultural relation policies in plural societies (Berry, 2013).

Berry's acculturation model describes four preferences ethnic/cultural minority members might have about how they want to live in intercultural contact situations. Two separate dimensions underlie these preferences: that of maintaining one's heritage, culture and identity ('culture maintenance'), and that of having contact with and participating in the larger society along with other ethnocultural groups ('contact'). These two dimensions of 'culture maintenance' and 'contact', lead to the four acculturation preferences: integration, assimilation, separation and marginalisation. When referring to strategies of the larger society, the same four preferences may be respectively defined: multiculturalism, melting pot, segregation and exclusion.

Many studies using this typology consistently show that favourable outcomes in well-being occur when people are oriented towards a multicultural strategy: they are interested in maintaining both their original culture and daily interactions with other groups (for a meta-analysis of studies influenced by this model, see Nguyen and Benet-Martinez, 2013). In this case, a strong, positive and significant association emerges with both psychological adjustment (higher life satisfaction and selfesteem; less alienation, anxiety, depression) and sociocultural adjustment (higher academic achievement, career success, greater civic and political participation; fewer behavioural problems, such as delinquency and risky sexual behaviours). Multicultural policies and programmes that promote the right of all people to maintain their own culture and to participate fully in the life of the larger society, and that push all groups (both the dominant and non-dominant) to engage in a process of mutual exchange and change, provide the cultural and psychological basis to enhance positive intercultural relations (Berry, 2011).

Another important trend of analysis concerns issues of identity development in multicultural contexts (Benet-Martinez and Hong, 2014). Research focuses on how and to what extent multicultural experiences promote the development of identities that are open-ended, adaptive, and aware of their 
socially constructed and contextually dependent character (Kim, 2008; Brunsma, et al. 2013). Overall, studies on multicultural identity suggest that persons who have significant exposure to multicultural situations are likely to develop multiple and flexible identities, they are less ethnocentric and more open to effective intercultural communication (Arasaratnam, 2013).

\section{Analysing everyday multicultural practices}

Finally, it is worth noting an increasing interest in 'everyday multiculturalism' (Wise and Velayutham, 2009) and 'everyday urban' (Amin, 2002), i.e., the daily negotiation of cultural difference in urban contexts. In this case, multiculturalism is conceived as neither a social policy challenge, nor an attitudinal issue (psychological attitude, individual adaptation). Instead, it is mainly conceived as a social practice: the mundane interaction in everyday life in intercultural contexts.

'Everyday multiculturalism' refers to both a category of analysis and a category of practices (Semi et $a l ., 2009)$. The former refers to an analytical perspective that aims to grasp the way in which people produce, reproduce, transform, and challenge cultural difference in everyday interactions, stressing the micro and macro conditions that make a specific social construction of cultural difference and identity possible and credible. Difference is viewed as a 'practice', an on-going performance, a political tool, as the local transformation of the reified representations of difference and belonging that are constructed on a global scale (in political discourse and the mass media) in relational tools, resources for action. As a category of practices, everyday multiculturalism focuses on the use of difference in localised spaces, on situations of 'banal' daily routines in which knowing how to 'face' and 'use' difference is a mundane, ordinary and necessary skill.

Analyses focusing on everyday multiculturalism generally use qualitative methodology ethnographic observation, in-depth interviews, focus groups and visual sociology - to highlight when, how, and in which way categorizations, belonging and identities are constructed and deconstructed in daily interactions (Noble et al., 1999; Sarat, 2002; Butcher and Harris, 2010).

Gerd Baumann (1996) has shown how people interacting in multicultural contexts have a dual discursive and practical competence when it comes to culture: they consider it both an essential, constitutive, reified 'given' and a processual, ongoing, ever-changing construct. Observing practical uses of difference in multicultural contexts, it is possible to go beyond the attempt to collocate people in fixed and stable categories (multiculturalists vs. assimilated vs. isolated vs. integralists) and to focus on the ways in which people construct, resist, translate and mediate social categories in daily relationships. The way in which people can use cultural difference in specific contexts reflects both structural constraints and agency (Blockland, 2003; Bernstein, 1997). An important aspect of focusing on everyday multiculturalism is the acknowledgment that contemporary multicultural societies are not simply collections of 'equal diversities', but reflect the power relations too. Consequently, an investigation of everyday multiculturalism is also an investigation of claim-making, expressions of citizenship and struggles for recognition (Harris, 2009: 191; Watson, 2009; Räthzel 2008; Back 1996).

Certain studies highlight the potential for cultural difference to be dissolved in everyday encounters through a process of mixing and hybridisation (Wilson, 2011; Wise, 2009; Wulfhorst et al., 2014). They stress the fact that some ordinary situations - everyday encounters at the city market or at the playground, exchange and gift relations among neighbours, etc. - create a feeling of being involved with others that produces tolerance and promotes inclusion. These studies advance a critique of multicultural policies aimed at reducing or stabilizing the minority group members' identity into narrow categories of belonging that hinder the mundane capacity to mix, change and find new arrangements.

Young people, in particular, show the capacity to use difference in strategic and tactical ways and take for granted the hybrid and fluid nature of belonging, identity and citizenship in contemporary multiple society (Harris 2013). Dual cultural competence becomes a necessary skill because being autonomous and self-fulfilled in a global society may mean not only claiming mobility rights, multiple belonging, hybrid and changeable identities, but also fighting for the recognition of common 
cultural roots, shared history, and the preservation of specific languages or habits from the tyranny of the dominant group, making use of alleged essentialist and reified identities (Yeĝenoĝlu, 2005).

In this constant shifting between reification, resistance, mediation and challenge, the concept of integration changes: it no longer only refers to being accepted, on an equal basis, by a local or national community; it also means being allowed to participate, without exclusion, in the global flux, claiming the right, if necessary, to freely manifest one's own differences and expect public recognition. Equality and difference become tools for claiming participation and avoiding exclusion. What is really at stake is not the recognition of strong and stable identities or differences, but inclusion in, or exclusion from, social contexts that may offer relevant material, symbolic, affective or ludic opportunities (Colombo 2010).

Others studies are more cautious against the tendency to romanticise intercultural encounters (Valentine 2008; Ho, 2011; Valentine and Sadgrove, 2012); they stress the importance of conflict and pay attention to power and sociospatial inequality. They criticize multiculturalist policies aimed at promoting intercultural encounters without taking social and political disparity and discrimination into account.

Examination of everyday practices invite analysis beyond the normative debate on the foundations of a fair multicultural society and to focus, instead, on how cultural difference is produced and negotiated and how social relations and identities are shaped and re-shaped in the process.

\section{Annotated further reading}

Gutmann A (ed.) (1994) Multiculturalism. Examining the Politics of Recognition. Princeton: Princeton University Press.

This edited volume presents, in the first part, Charles Taylor's ground-breaking paper The Politics of Recognition with the comments by Susan Wolf, Steven Rockefeller and Michael Walzer. The second part contains other two relevant contributions by Jürgen Habermas and Antony Appiah. It collects some of the seminal work that set the stage for the normative philosophical debate about the importance and the pitfalls of recognizing cultural difference in liberal states.

Kymlicka W (1995) Multicultural Citizenship. Oxford: Oxford University Press.

A classic text that attempts to suggest some key concepts and principles for a liberal approach to minority rights. In particular, it argues that some collective rights may be perfectly consistent with liberal democratic tradition and suggests some criteria to supplement liberal individual rights with minority rights.

Barry B (2001) Culture \& Equality. An Egalitarian Critique of Multiculturalism. Cambridge: Polity Press.

One of the most influential and radical liberal critiques of multiculturalism. It defends universalistic citizenship stating that rights accorded on the basis of cultural group membership contradict egalitarian liberal norms and lessen individual freedom.

Benhabib S (2002) The Claims of Culture: Equality and Diversity in the Global Era. Princeton: Princeton University Press.

This book goes beyond the exhausted debate about the conflict and the irreconcilability between individual and collective rights or liberal and communitarian philosophy. Criticising an essentialist idea of culture, it develops Habermas' ideas of communicative reason or communicative rationality and proposes deliberative democracy as a practical way to expand individual rights through the recognition of collective belonging.

Gunew S (2004) Haunted Nations. The colonial dimension of multiculturalism. London: Routledge. A significant example of the importance of a postcolonial perspective on and a comparative historical analysis of multiculturalism. It highlights the ways in which relations between cultural 
minorities and majorities operated, embedded in specific moments in history and related to the politics of race and indigeneity.

Vertovec S. and Wessendorf S (eds) (2010) The Multicultural Backlash. European discourses, policies and practices. London: Routledge.

This edited volume presents seven European and two Canadian empirical analysis contrasting the alleged end of multiculturalism. It provides an informed assessment of recent and current multiculturalism backlash, suggesting that the emerging scepticism toward multicultural policies has gained ground more in public discourses than in policy-making. It highlights how public rhetoric shifted from multiculturalism to social cohesion and integration, but suggests that this discourse shift is not actually reflected in everyday practices.

Modood T (2007) Multiculturalism. A Civic Idea. Cambridge: Polity Press

An example of a defence of multiculturalism grounded in a concept of equal citizenship able to recognise the importance of group membership. Specific attention is devoted to arguing for the importance of allowing group identity politics and within that to include religious identity politics when it is a means of empowering the excluded.

Phillips A (2007) Multiculturalism without Culture, Princeton: Princeton University press

Another important example of rethinking multiculturalism avoiding essentialism and the reification of existing cultural differences. Specific attention is devoted to a gendered perspective on multiculturalism placing individual agency at its core.

Wise A and Velayutham S (eds) (2009) Everyday Multiculturalism. Basingstoke: Palgrave Macmillan.

This edited book explores everyday lived experiences of multicultural relationships in the urban context. It proposes a sociological perspective that goes beyond normative preoccupations of how society should be and empirically analyses how people manage, use and contest cultural difference in order to give meaning to their daily experience.

Rattansi A (2011) Multiculturalism. A Very Short Introduction. Oxford: Oxford University Press. An introductory albeit rigorous and sophisticated text that reviews major issues in the field and suggests possible directions for moving on from multiculturalism and its most critical pitfalls.

Baumann G and Vertovec S (eds) (2011) Multiculturalism. Critical Concepts in Sociology. London: Routledge.

This four-volume anthology constitutes a useful collection of some of the most relevant contributions to the multicultural debate. It incorporates a large number of authors and a wide range of topics. The re-published articles range from criticism of the idea of a plural society in the 1960s and 1970s, to the central topics in multicultural discussions in the 1990s, up to the most recent debates about the alleged crisis and transformations of multiculturalism.

\section{References}

Alexander JC (2001) Theorizing the 'Modes of Incorporation': Assimilation, Hyphenation, and Multiculturalism as Varieties of Civil Participation. Sociological Theory 19 (3): 237-249.

Alexander JC (2103) Struggling over the mode of incorporation: backlash against multiculturalism in Europe. Ethnic and Racial Studies 36 (4): 531-556.

Al-Hibri AY (1999) Is Western Patriarchal Feminism Good for Third World/Minority Women? In Cohen J, Howard M and Nussbaum M (eds) Is Multiculturalism Bad for Women? Princeton: Princeton University Press, 41-46.

Amin A (2002) Ethnicity and the multicultural city: living with diversity. Environment and Planning A 34: 959-980.

Amselle JL (1990) Logiques métisses: anthropologie de l'identité en Afrique et ailleurs, Paris : Payot. 
Anderson CJ and Paskeviciute A (2006) How Ethnic and Linguistic Heterogeneity Influence the Prospects for Civil Society: A Comparative Study of Citizenship Behavior. Journal of Politics 68(4): 783-802.

Anthias F (2002) Beyond Feminism and Multiculturalism: Locating Difference and the Politic of Location. Women's Studies International Forum 25(3): 275-286.

Agirdag O, Van Houtte M and Van Avermaet P (2011) Ethnic School Context and the National and Sub-national Identifications of Pupils. Ethnic and Racial Studies 34(2): 357-78.

Arasaratnam LA (2013) A review of articles on multiculturalism in 35 years of IJIR. International Journal of Intercultural Relations 37(6): 676-685.

Ariely G (2013) Does Diversity Erode Social Cohesion? Conceptual and Methodological Issues. Political Studies 00: 1-23 (accessed 12 August 2014).

Auster L (2004) How the Multicultural Ideology Captured America. The Social Contract 14(2): 197208.

Back L (1996) New Ethnicities and Urban Culture: Racism and Multiculture in Young Lives. London: Routledge.

Back L, Keith M, Khan A, Shukra K and Solomos J (2002) New Labour's White Heart: Politics, Multiculturalism and the Return of Assimilation. The Political Quarterly, 73(4): 445-454.

Back L, Shamser S and Charlynne B (2012) New Hierarchies of Belonging. European Journal of Cultural Studies, 15(2): 139-154.

Banting K and Kymlicka W (eds) (2006) Multiculturalism and The Welfare State: Recognition and redistribution in contemporary democracies. New York: Oxford University Press.

Banting K and Kymlicka W (2013) Is there really a retreat from multiculturalism policies? New evidence from the multiculturalism policy index. Comparative European Politics 11(5): 577598.

Banting K, Johnston R, Kymlicka W and Soroka S. (2006) Do multiculturalism policies erode the welfare state? An empirical analysis. In: Banting K and Kymlicka W (eds) Multiculturalism and The Welfare State: Recognition and redistribution in contemporary democracies. New York: Oxford University Press, 49-91.

Barry B (2001) Culture \& Equality. An Egalitarian Critique of Multiculturalism. Cambridge: Polity Press.

Baumann G (1996) Contesting Culture: Discourses of Identity in Multi-Ethnic London. Cambridge: Cambridge University Press.

Baumann G (1999) The Multicultural Riddle. New York: Routledge.

Beck U (2006) Cosmopolitan Vision. Cambridge: Polity Press.

Benet-Martinez V and Hong YY (eds) (2014) The Oxford Handbook of Multicultural Identity. New York: Oxford University Press.

Benhabib S (2002) The Claims of Culture: Equality and Diversity in the Global Era. Princeton: Princeton University Press.

Bernstein M (1997) Celebration and Suppression: The Strategic Uses of Identity by the Lesbian and Gay Movement. The American Journal of Sociology 103(3): 531-565.

Berry JW (1974) Psychological aspects of cultural pluralism. Culture Learning 2: 17-22.

Berry JW (1980) Acculturation as varieties of Adaptation. In: Padilla A (ed.) Acculturation: Theory, models and some new findings. Boulder: Westview Press, 9-25.

Berry JW (2011) Integration and Multiculturalism: Ways towards Social Solidarity. Papers on Social Representations 20(2): 1-21.

Berry JW (2013) Intercultural Relations in Plural Societies: Research Derived from Multiculturalism Policy. Acta de investigación psicológica 3(2): 1122-1135.

Berry JW, Phinney JS, Sam DL and Vedder P (eds) (2006) Immigrant Youth in Cultural Translation. Mahwah: Lawrence Erlbaum Associates.

Blockland T (2003) Ethnic Complexity: Routes to Discriminatory Repertoires in an Inner-city Neighbourhood. Ethnic and Racial Studies 26(1): 1-24. 
Bloemraad I (2006) Becoming a Citizen: Incorporating Immigrants and Refugees in the United States and Canada. Berkeley: University of California Press.

Bloemraad I, Korteweg A and Yurdakul G (2008) Citizenship and Immigration: Multiculturalism, Assimilation, and Challenges to the Nation-State. Annual Review of Sociology 34: 153-159.

Brubaker R (2001) The Return of Assimilation? Changing Perspectives on Immigration and Its Sequels in France, Germany, and the United States. Ethnic and Racial Studies 24(4): 531-548.

Brunsma DL, Delgado D. and Rockquemore KA (2013) Liminality in the Multiracial Experience: Towards a Concept of Identity Matrix. Identities: Global Studies in Culture and Power 20(5): 481-502.

Butcher M and Harris A (2010) Pedestrian Crossing: Young People and Everyday Multiculturalism. Journal of Intercultural Studies 31(5): 449-453.

Citrin J, Levy M. and Wright M (2014) Multicultural Policy and Political Support in European Democracies. Comparative Political Studies 47: 1531-1557.

Colombo E (2010) Crossing Difference: How Young Children of Immigrants Keep Everyday Multiculturalism Alive. Journal of Intercultural Studies 31(5): 455-470.

Constant F (2000) Le multiculturalisme. Paris: Flammarion.

Derrida J (1972) La Dissémination. Paris: Editions du Seuil.

Eizaguirre S, Pradel M, Terrones A, Martinez-Celorrio X and Garcia M (2012) Multilevel Governance and Social Cohesion: Bringing Back Conflict in Citizenship Practices. Urban Studies 49(9): 1999-2016.

Evans G and Need A (2002) Explaining ethnic polarization over attitudes towards minority rights in Eastern Europe: a multilevel analysis. Social Sciences Research 31(4): 653-680.

Fraser N (1997) Justice Interruptus. Critical Reflections on the "Postsocialist" Condition. New York and London: Routledge.

Fraser N (2007) Identity, Exclusion, and Critique: A Response to Four Critics. European Journal of Political Theory 6(3): 305-338.

Gilroy P (2005) Postcolonial Melancholia. New York. Columbia University Press.

Gilroy P (2006) Multiculturalism and Post-colonial Theory. In Dryzek J, Honig B and Phillips A (eds) The Oxford Handbook of Political Theory. Oxford: Oxford University Press, 656-674.

Gilroy P (2012) 'My Britain is fuck all' zombie multiculturalism and the race politics of citizenship. Identities: Global studies in Cultures and Power 19(4): 380-397.

Gitlin T (1995) The Twilight of Common Dreams: Why America is Wracked by Culture Wars. New York: Metropolitan Books.

Glazer N (1997) We Are All Multiculturalists Now. Cambridge: Harvard University Press.

Goldberg DT (1994) Multiculturalism. A Critical Reader. Oxford: Blackwell.

Goodhart D (2004) Too diverse? Is Britain becoming too diverse to sustain the mutual obligations behind a good society and the welfare state? Prospect 95: 30-37.

Goodman SW (2010) Integration Requirements for Integration's Sake? Identifying, Categorising and Comparing Civic Integration Policies. Journal of Ethnic and Migration Studies 36(5): 753-772.

Grillo R (2007) An excess of alterity? Debating difference in a multicultural society. Ethnic and Racial Studies 30(6): 979-998.

Gunew S (2004) Haunted Nations. The colonial dimension of multiculturalism. London: Routledge.

Habermas J (1994) Struggles for Recognition in the Democratic Constitutional State. In Gutmann A (ed.) Multiculturalism. Examining the Politics of Recognition. Princeton: Princeton University Press, 107-148.

Habermas J (2001) Postnational Constellation: Political Essays. Cambridge MA: The MIT Press.

Hage G (2000) White Nation: Fantasies of White Supremacy in a Multicultural Society. New York: Routledge.

Hall S (2000) Conclusion: the Multi-cultural Question. In Hesse B (ed.) Unsettled multiculturalisms: Diasporas, entanglements, transruptions. London: Zed Books, 209-241. 
Hannerz U (1992) Cultural Complexity: Studies in the Social Organization of Meaning. New York: Columbia University Press.

Harris A (2009) Shifting the boundaries of cultural spaces: young people and everyday multiculturalism. Social Identities: Journal for the Study of Race, Nation and Culture 15(2): 187205.

Harris A (2013) Young People and Everyday Multiculturalism. New York: Routledge.

Heath A and Demireva N (2014) Has multiculturalism failed in Britain? Ethnic and Racial Studies 37(1): 161-180.

Hollinger DA (1995) Postethnic America. Beyond Multiculturalism. New York: Basic Books.

Ho C (2011) Respecting the Presence of Others: School Micropublics and Everyday Multiculturalism. Journal of Intercultural Studies 32(6): 603-619.

Honig B (1999) 'My Culture Made Me Do It'. In Cohen J, Howard M and Nussbaum M (eds) Is Multiculturalism Bad for Women? Princeton: Princeton University Press, 35-40.

Honneth A (1996) The Struggle for Recognition: The Moral Grammar of Social Conflicts Cambridge MA: The MIT Press.

Hooghe M, Reeskens T, Stolle D. and Trappers A. (2009) Ethnic Diversity and Generalized Trust in Europe. Comparative Political Studies, 42(2): 198-223.

Huntington SP (1996) The clash of civilization and the Remaking of World Order. New York: Simon $\&$ Schuster.

Huntington SP (2004) Who Are We? The Challenges to America's National Identity. New York: Simon \& Schuster.

Joppke C (2004) The Retreat of Multiculturalism in the Liberal State: Theory and Policy. The British Journal of Sociology 55(2): 237-257.

Joppke C (2007) Beyond national models: civic integration policies for immigrants in Western Europe. West European Politics 30(1): 1-22.

Joppke C (2008) Immigration and the identity of citizenship: the paradox of universalism. Citizenship Studies 12(6): 533-546.

Kesler C and Bloemraad I (2010) Does Immigration Erode Social Capital? The Conditional Effects of Immigration-Generated Diversity on Trust, Membership, and Participation across 19 Countries. Canadian Journal of Political Science 43(2): 319-347.

Kim YY (2008) Intercultural Personhood: Globalization and a way of being. International Journal of Intercultural Relations 32(4): 359-368.

Kivisto P (2010) Multiculturalism and Racial Democracy: State Policies and Social Practices. In: Collin PH and Solomos J (eds) The Sage Handbook of Race and Ethnic Studies. London: Sage, 253-274.

Koopmans R (2010) Trade-Offs between Equality and Difference: Immigrant Integration, Multiculturalism and the Welfare State in Cross-National Perspective. Journal of Ethnic and Migration Studies 36(1): 1-26.

Koopmans R (2013) Multiculturalism and Immigration: A Contested Field in Cross-National Comparison. Annual Review of Sociology 39: 147-169.

Kundnani A (2012) Multiculturalism and its discontents: Left, Right and liberal. European Journal of Cultural Studies 15(2): 155-166.

Kymlicka W (1995) Multicultural Citizenship. Oxford: Clarendon Press.

Kymlicka W (2012) Multiculturalism: Success, Failure, and the Future. Washington DC: Migration Policy Institute.

Laurence J (2011) The Effect of Ethnic Diversity and Community Disadvantage on Social Cohesion: A Multi-level Analysis of Social Capital and Interethnic Relations in UK Communities. European Sociological Review 27(1): 70-89.

Lentin A and Titley G (2012) The crisis of 'multiculturalism' in Europe: Mediated minarets, intolerable subjects. European Journal of Cultural Studies 15(2): 123-138. 
Lesińska M (2014) The European backlash against immigration and multiculturalism. Journal of Sociology 50(1): 37-50.

Levey GB (2012) Interculturalism vs. Multiculturalism: A Distinction without a Difference? Journal of Intercultural Studies 33(2): 217-224.

Levy JT (2000) The Multiculturalism of Fear. Oxford: Oxford University Press.

Liu S (2007) Living with others: Mapping the routes to acculturation in a multicultural society. International Journal of Intercultural Relations 31(6): 761-778.

Malik K (2009) From Fatwa to Jihad: the Rushdie Affair and Its Legacy. London: Atlantic.

May S (ed.) (1999) Critical Multiculturalism. Rethinking Multicultural and Antiracist Education. London: Falmer Press.

McLaren LM (2003) Anti-immigrant prejudice in Europe: contact, threat perception, and preferences for the exclusion of migrants. Social Forces 81(3): 909-936.

McLaren P (1997) Revolutionary Multiculturalism. Pedagogies of Dissent for the New Millennium. Boulder: Westview Press.

Melucci A (1996) Challenging Codes. Collective action in the information age, Cambridge: Cambridge University Press.

Miller D (2002) Liberalism, Equal Opportunities and Cultural Commitments. In Kelly P (ed.) Multiculturalism Reconsidered. Culture and Equality and its Critics. Cambridge: Polity Press, 45-61.

Modood T (2007) Multiculturalism. A Civic Idea. Cambridge: Polity Press.

Narayan U and Harding S (eds) (2000) Decentering the Center: Philosophy for a Multicultural, Postcolonial, and Feminist World. Bloomington: Indiana University Press.

Nguyen AD and Benet-Martínez V (2013) Biculturalism and Adjustment: A Meta-Analysis. Journal of Cross-Cultural Psychology 44(1): 122-159.

Noble G, Poynting S and Tabar P (1999) Youth, Ethnicity and the Mapping of Identities: Strategic Essentialism and Strategic Hybridity among Male Arabic-speaking Youth in South-western Sydney. Communal/Plural 7(1): 29-44.

Okin SM (1999) Is Multiculturalism Bad for Women? In Cohen J, Howard M and Nussbaum M (eds) Is Multiculturalism Bad for Women? Princeton: Princeton University Press, 7-24.

Ong A (1999) Flexible Citizenship: The Cultural Logic of Transnationality. Durham: Duke University Press.

Pakulski J and Markowski S (2014) Globalisation, immigration and multiculturalism - the European and Australian experiences. Journal of Sociology 50(1): 3-9.

Parekh B (2002) Rethinking Multiculturalism: Cultural Diversity and Political Theory. Harvard: Harvard University Press.

Paxton P. and Mughan A. (2006) What's to Fear from Immigrants? Creating an Assimilationist Threat Scale. Political Psychology, 27(4): 549-568.

Phillips A (2007) Multiculturalism without Culture. Princeton: Princeton University Press.

Putnam RD (2000) Bowling Alone: The Collapse and Revival of American Community. New York: Simon \& Schuster.

Putnam RD (2007) E Pluribus Unum: Diversity and Community in the Twenty-First Century - the 2006 Johan Skytte Prize Lecture. Scandinavian Political Studies, 30(2): 137-74.

Poynting S and Mason V (2007) The resistible rise of Islamophobia. Anti-Muslim racism in the UK and Australia before 11 September 2001. The Journal of Sociology 43(1): 61-86.

Poynting S, Noble G, Tabar P and Collins J (2004) Bin Laden in the Suburb. Criminalising the Arab Other. Sydney: The Sydney Institute of Criminology.

Quillian L (1995) Prejudice as a response to perceived group threat: population composition and antiimmigrant and racial prejudice in Europe. American Sociological Review 60(4): 586-611.

Ratcliffe P and Newman I (eds.) (2011) Promoting Social Cohesion: Implications for Policy and Evaluation. Bristol: Policy Press.

Räthzel N (ed.) (2006) Finding the Way Home. Göttingen: V\&R unipress. 
Rattansi A (1999) Racism, 'Postmodernism' and Reflexive Multiculturalism, in May S (ed.) Critical Multiculturalism. Rethinking Multicultural and Antiracist Education. London: Falmer Press, 77112.

Rattansi A (2011) Multiculturalism: A Very Short Introduction, Oxford: Oxford University Press.

Reitz JG, Breton R, Dion KK and Dion KL (2009) Multiculturalism and Social Cohesion. Potentials and Challenges of Diversity, New York: Springer.

Rex J (1996) Ethnic Minorities in the Modern Nation State. Houndmills: MacMillan.

Romeyn E (2014) Anti-Semitism and Islamophobia: Spectropolitics and Immigration. Theory, Culture \& Society, 0(0): 1-25 (accessed 15 April 2014).

Rorty R (1989) Contingency, Irony, and Solidarity. Cambridge: Cambridge University Press.

Sarat A (2002) The Micropolitics of Identity-Difference: Recognition and Accomodation in Everyday Life. In Shweder RA, Minow M and Markus HR (eds) Engaging Cultural Differences. The Multicultural Challenge in Liberal Democracies New Youk: Russel Sage Foundation, 396-416.

Schlesinger AM (1998), The Disuniting of America: Reflections on a Multicultural Society (Revised and Enlarged Edition). New York: Norton.

Semi G, Colombo E, Camozzi I and Frisina A (2009) Practices of Difference: Analysing Multiculturalism in Everyday Life. In Wise $\mathrm{A}$ and Velayutham $\mathrm{S}$ (eds) Everyday Multiculturalism. Basingstoke: Palgrave Macmillan, 66-84.

Semprini A (1997) Le multiculturalisme. Paris: PUF.

Shohat E and Stam R (1994) Unthinking Eurocentrism. Multiculturalism and the Media. London: Routledge.

Song S (2010) Multiculturalism. In: Zalta EN (ed.) The Stanford Encyclopedia of Philosophy. Available at http://plato.stanford.edu/archives/spr2014/entries/multiculturalism/ (Accessed 23 April 2014).

Sturgis P, Brunton-Smith I, Read S and Allum N. (2011) Does Ethnic Diversity Erode Trust? Putnam's 'Hunkering down' Thesis Reconsidered. British Journal of Political Science 41(1):5782.

Taylor C (1994) The Politics of Recognition. In Gutmann A (ed.) Multiculturalism. Examining the Politics of Recognition. Princeton: Princeton University Press, 25-74.

Thomas P (2011) Youth, Multiculturalism and Community Cohesion. New York: Palgrave Macmillan.

Touraine A (1997) Pourrons-nous vivre ensemble? Paris : Fayard.

Triandafyllidou A, Modood T and Meer N (eds) (2012) European Multiculturalism. Cultural, Religious and Ethnic Challenges, Edinburgh: Edinburgh University Press.

Valentine G (2008) Living with Difference: Reflections on Geographies of Encounter. Progress in Human Geography 32(3): 323-337.

Valentine $\mathrm{G}$ and Sadgrove J (2012) Lived difference: a narrative account of spatiotemporal processes of social differentiation. Environment and Planning A 44(9): 2049-2063.

Verkuyten M and Brug P (2004) Multiculturalism and group status: The role of ethnic identification, group essentialism and protestant ethic. European Journal of Social Psychology, 34(6): 647-661.

Verkuyten M and Martinovic B (2006) Understanding multicultural attitudes: The role of group status, identification, friendships, and justifying ideologies. International Journal of Intercultural Relations 30(1): 1-18.

Verkuyten M and Thijs $\mathbf{J}$ (2002) Multiculturalism among minority and majority adolescents in the Netherlands. International Journal of Intercultural Relations 26(1): 91-108.

Vertovec S and Wessendorf S (eds) (2010) The Multiculturalism Backlash. New York: Routledge.

Walsh JP (2014) The marketization of multiculturalism: neoliberal restructuring and cultural difference in Australia, Ethnic and Racial Studies 37(2): 280-301.

Watson S (2009) Brief Encounters of Unpredidictable Kind: Everyday Multiculturalism in Two London Street Markets. In Wise A and Velayutham S (eds) Everyday Multiculturalism. Basingstoke: Palgrave Macmillan, 125-139. 
Weldon SA (2006). The institutional context of tolerance for ethnic minorities: A comparative, multilevel analysis of Western Europe. American Journal of Political Science, 50, 331-349.

Werbner P (2005) The translocation of culture : 'Community' cohesion and the force of multiculturalism in history. The Sociological Review 53(4): 745-768.

Wieviorka M (ed.) (1996) Une société fragmentée? Le multiculturalisme en débat. Paris: La Découverte.

Wieviorka M (1998) Is multiculturalism the solution? Ethnic and racial studies 21(5): 881-910.

Wieviorka M (2013) The re-enchantment of universal values. Ethnic and Racial Studies 36(12): 1943-1956.

Wilson HF (2011) Passing propinquities in the multicultural city: the everyday encounters of bus passengering. Environment and Planning A 43 634-649

Wise A (2009) Everyday Multiculturalism: Transversal Crossing and Working Class Cosmopolitans. In Wise $\mathrm{A}$ and Velayutham S (eds) Everyday Multiculturalism. Basingstoke: Palgrave Macmillan, 21-45.

Wise A and Velayutham S (eds) (2009) Everyday Multiculturalism. Basingstoke: Palgrave Macmillan.

Wright M (2011) Policy Regimes and Normative Conceptions of Nationalism in Mass Public Opinion. Comparative Political Studies 44(5): 598-624.

Wright M, Bloemraad I (2012) Is There a Trade-off between Multiculturalism and Socio-Political Integration? Policy Regimes and Immigrant Incorporation in Comparative Perspective. Perspective on Politics 10(1): 77-95.

Wulfhorst C, Rocha C and Morgan G (2014) Intimate Multiculturalism: Transnationalism and Belonging amongst Capoeiristas in Australia. Journal of Ethnic and Migration Studies 00: 1-19 (accessed 15 August 2014).

Yeĝenoĝlu M (2005) Cosmopolitanism and Nationalism in a Globalized World. Ethnic and Racial Studies 28(1): 103-131.

Young IM (1990) Justice and the Politics of Difference. Princeton: Princeton University Press.

Young R (1995) Colonial Desire: Hybridity in Culture, Theory and Race. London: Routledge.

Yuval-Davis N (1999) Ethnicity, Gender Relations and Multiculturalism, in Torres R.D., Mirón L. and Xavier Inda J. (eds.) Race, Identity and Citizenship: A Reader. Oxford: Wiley-Blackwell, pp. 112-125.

Yuval-Davis N, Anthias F and Kofman E (2005) Secure borders and safe haven and the gendered politics of belonging: Beyond social cohesion. Ethnic and Racial Studies, 28(3): 513-535.

Zagefka H, Brown R, Broquard M and Leventoglu Martin SL (2007) Predictors and consequences of negative attitudes toward immigrants in Belgium and Turkey: The role of acculturation preferences and economic competition. British Journal of Social Psychology, 46, 153-169.

Enzo Colombo is professor of Sociology of Intercultural Relations at the University of Milan, Italy. His interests include the social representation of Otherness, new form of racism, and the transformation of citizenship. He is the author of several articles and books, including Children of Immigrants in a Globalized World. A generational Perspective (with P. Rebughini) (2012). [email: enzo.colombo@unimi.it] 